\title{
The Nature of the EU Labour Market and Its Regulations
}

\author{
Az EU munkaerőpiacának jellemzői és szabályozása
}

\begin{abstract}
Labour market regulation to prevent labour migration easily becomes protectionist, thus violating the rights of migrant workers. This paper focuses especially on the role of the labour market regulations relating to migrant workers in the EU. General labour market regulations will be analysed in the first section. When we talk about the labour market, the regulations will be assessed as to whether they are strong or not and to what extent the workers will get their rights protected. EU labour migration is large around the world and can be handled with labour legislation and the labour market. Therefore, EU labour market regulations and policies, especially active labour market policies, are analysed in this paper.
\end{abstract}

Keywords: labour market, European Union, active labour market policies, employer, migrant worker

\begin{abstract}
ABSZTRAKT
A munkaerőpiac szabályozása a munkaerő-vándorlás megelőzése érdekében könnyen protekcionistává válik, ezzel megsértve a migráns munkavállalók jogait. Jelen tanulmány a migráns munkavállalókkal kapcsolatos munkaerő-piaci szabályozások szerepére összpontosít az EU-ban, de kitér a munkaerőpiaci szabályozások általános jellemzőire is. A munkaerőpiaci szabályozások értékelése során egy ilyen típusú szabályozás „ereje” tipikusan attól függ, hogy mennyiben védik az államok a migráns munkavállalók alapvető jogait. Az EU-ra jellemző munkaerő-vándorlás világviszonylatban is jelentősnek számít, ez pedig hatékony munkaerőpiaci szabályozást tesz szükségessé a felmerülő nehézségek kezelése céljából. Minderre tekintettel jelen tanulmány az EU legfontosabb munkaeröpiaci szabályozásait és politikáit dolgozza fel, különös tekintettel az aktív munkaerőpiaci eszközökre és megoldásokra.
\end{abstract}

Kulcsszavak: munkaerőpiac, Európai Unió, aktív munkaerőpiaci politikák, munkáltató, migráns munkavállaló

The nature of the labour market is to be flexible in the supply and demand of the workforce in a specific region. It is important and essential for employers and employees. Without its regulations, there would be a chaotic situation where employers do not have any mutual or multi-lateral agreements in order to find workers. The labour market can place members of the workforce in suitable places suitable places and balance the demand and supply for employment.

* Thazin Khaing Moe, PhD student, University of Debrecen (Hungary) Géza Marton Doctoral School of Legal Studies; Assistant lecturer, University of Magway Department of Law (Myanmar); e-mail: thazinkhaingmoe@ gmail.com. The study was made under the scope of the Ministry of Justice's program on strengthening the quality of legal education. 
Before examining the nature of the labour market, we need to know firstly the terms of the supply of labour and the demand for labour. When the employers have a vacancy for some position in their employment, they have to find workers not only internally but also in international marketplaces. It is about the labour demand. In case the workers correspond to the skills of what the employers need, they can fill the vacant positions. This is about labour supply. The place that the labour supply and demand can be managed is the labour market.

My paper has three sections, which are the nature of the labour market, regulations of the labour market and labour market regulations in the EU. Section 1 deals only with the nature of the labour market including labour market flexibility. Section 2 mentions the regulations of the labour market in general which involves minimum wages, working conditions and active labour market policies. Section 3 mainly focuses on the European labour market regulation that includes the flexible labour market in the EU, ALMP in the EU, the expenditures on ALMP in the EU and labour migration in European labour markets.

My hypothesis is based on three research questions: (1) What is the role of labour market for migration? (2) Should the labour market be regulated with flexible rules? (3) Does the pandemic situation affect the labour market in EU?

I apply the qualitative method because some EU Member States' market policies are compared and the literature has to be referred to. The theoretical approach has to be used because my reviews or my theoretical thoughts are expressed in each paragraph. Inductive and deductive reasoning is also utilised for my conclusion.

\section{The Nature of the Labour Market}

The labour market or the job market refers to the supply of and demand for labour, in which employees provide the supply and employers provide the demand. It is a major component of any economy and is intricately linked to markets for capital, goods, and services. ${ }^{1}$ Angela Refalo describes it as "a commodity, which is applied by humans and how this commodity is bought and sold by the employer within the job market." The Economic Times defines it as "the place where workers and employees interact with each other." ${ }^{3}$ In the labour market, employers compete to hire the best, and the workers compete for the best satisfying job. Beligrădeanu and Stefanescu define the labour market as the confrontation between the supply and demand of labour in a given timeframe and geographic area that is usually completed through employment (with an individual employment contract). ${ }^{4}$ Therefore, it is a kind of market, where the workers can get job with their skills and the employers

1 Will Kenton, 'Labor Market' (Investopedia, 31 August 2020) <https://www.investopedia.com/terms///labormarket.asp> accessed 20 December 2020.

2 Angela Refalo, 'Labour Market Themes, Issues and Controversies' <https://www.academia.edu/3639736/ Labour_Market_Flexibility> accessed 20 December 2020.

3 <https://economictimes.indiatimes.com/definition/Labour-Market> accessed 20 December 2020.

${ }^{4}$ Paşca Cornelia Serena, 'Labour Market - Concepts, Functions, Features, Patterns' (2016) 34(4) Management Strategies Journal 201. 
can fill their demand. The participants concerning the labour market are the workers, the employers and their representatives. In that market, many agreements and contracts for jobs can be implemented. Even the workers with low skills can find jobs in the labour market as the employers set their desired skills in accordance with their required vacancy. It makes things easy for the buyers and sellers and balances the demand and supply for both sides.

All labour markets have their self-regulation mechanism, which balances the labour resources of the national economy and the possibilities. Commonly the factors of the mechanism are supply, demand and price. It is segmented: primary, secondary and tertiary. The primary sector means the workers with high qualifications and education level. The secondary sector includes workers who have low skills and education and the tertiary sector relates to undeclared work. ${ }^{5}$ For the workers with high skills, there are several positions and jobs of high remuneration. They can easily get a permanent position. The ones with low qualifications, normally, cannot get a great salary. In general, not every receiving country will provide a good opportunity for the uneducated or workers who have low skills.

The market can also be divided into two types, these being flexible and strict labour markets. In this section, the flexible market will be favourably discussed. The regulations of the job market are important in order to create a market that would otherwise be invalid and chaotic without the rules or regulations. Some countries build strict rules and regulations into their labour markets, while some are flexible. The policies in each region and state are different depending on the social, political and economic conditions. Regions such as Europe and America have some specific policies and conventions, but each Member State in their specific region has different legislation and policies regarding the national labour market.

Labour market flexibility, as Will Kenton describes it, is "an important part of the labour market. It allows companies to make certain decisions about changing their labour force as a response to fluctuations in the market and to help boost production." 6 In every market, there is a fluctuation according to the current conditions. The labour market also faces that situation, for example, wages, hiring and firing of workers, working conditions, etc. For dealing with these issues, labour market flexibility has to be established with the best regulations. Therefore, labour market flexibility is a kind of adjustment of some flexible rules in line with the agreements of the employers in the labour market.

Some authors have other definitions for the term "labour market flexibility" based on their studies and own way of thinking. Raul Eamets and Tiiu Paas stated four different aspects, which are external numerical flexibility (worker hiring and firing), internal numerical flexibility (working hours), functional flexibility (changing the content of the work) and wage flexibility (remuneration) in accordance with OECD. ${ }^{7}$ Friedrich

\footnotetext{
${ }^{5}$ Ibid 203.

${ }^{6}$ Will Kenton, 'Labor Market Flexibility' (Investopedia, 18 April 2021) <https://www.investopedia.com/terms/// labor-market-flexibility.asp> accessed 20 December 2020.

${ }^{7}$ Raul Eamets and Tiiu Paas, 'Labour Market Flexibility and Flexicurity' (2006) 3. <https://www.researchgate. net/publication/236283207> accessed 20 December 2020.
} 
Klau and Axel Mittelstade also argue that there are four broad aspects. These are real labour cost flexibility at the economy-wide level, adaptability of relative labour costs across occupations and enterprises, labour mobility and flexibility of working time and work schedules. ${ }^{8}$ Therefore, when we define labour market flexibility, basically, working conditions, wage and unemployment are important to every worker. In order to make the labour market flexible, the employers are essential and play the vital role in changing better rules of the market. It means that only the employers should create and do the flexible rules for all the affairs of the market.

When labour market flexibility is being stipulated, security needs to be clarified as the terms of flexibility and security are mainly connected to the labour market. The flexibility and security are the same, but depend on each other in the labour market. ${ }^{9}$ Peter Auer of International Labour Organization mentioned the dimensions of security that are job security, employment security/employability security, income security and combination security. ${ }^{10}$ In the case of flexible rules in the labour market, the security will be weaker than in the case of strict rules in the market. Peter Auer's security dimensions are necessary as they are the fundamental requirements, which the employer shall set.

The nature of the flexible regime will be less secure. Therefore, if there are so many job opportunities, the workers will get economical security, but not complete employment protection. At times of economic recession, flexible labour markets might provoke a decline in demand, which only worsens the recession. ${ }^{11}$ If labour market restrictions are high, the unemployment rate will be raised automatically and it would force illegal behaviour to strengthen. Flexibility is one of the great ways to create a larger workforce that develops the factories or industries with their vacancies and pushes them faster regarding the running of their industries.

\section{Regulations of the Labour Market}

Every market has its own rules and regulations to control illegal practices or behaviour within the market. The market without regulations or rules cannot carry on development for a long period and forces the workers to act in an illegal or irregular fashion. The International Labour Organization does not have any specific convention for labour markets, but instead each region sets its own policies or regulations regarding their labour market. Depending on the nature of a labour market, a question must be asked: should the legislation of labour market be made with so many

${ }^{8}$ Friedrich Klau and Axel Mittelstade, 'Labour Market Flexibility' (2014) 10. <www.oecd.org/economy/growth/ 35558438.pdf> accessed 20 December 2020.

9 Peter Auer, 'Security in labour markets: Combining flexibility with security for decent work' $(2007)<$ https:// www.ilo.org/wcmsp5/groups/public/---ed_emp/---emp_elm/---analysis/documents/publication/wcms_113923. pdf $>$ accessed 20 December 2020.

10 Ibid 2.

11 Colin Crouch, 'European Employment and Labour Market Policy' (BBVA Open Mind, 2016) <https://www. bbvaopenmind.com/en/articles/european-employment-and-labour-market-policy/> accessed 20 December 2020. 
restrictions? As far as the current and past policies are concerned, it is clear that there is no strong or perfect legislation regarding this. It would be an improvement on the current rules or policies if there would be an attempt to promote and develop the markets in order to protect the workers' rights.

Labour market regulations restrict some limitations on employment contracts, working conditions and working hours. ${ }^{12}$ It involves labour market institutions and labour market policies. Labour market policies include regulative ones influencing the interaction between labour supply and demand. ${ }^{13}$ In order to get better jobs and develop labour markets, the ILO stipulates the importance of the policies. ${ }^{14}$ The ILO provides that "representatives of the employers and the workers shall be consulted concerning employment policies, with a view to taking fully into account their experience and views and securing their full co-operation in formulating and enlisting support for such policies." 15 Types of employment contracts, wages and benefits, working conditions, employment practices and social protection are critical and included in the labour market regulations. ${ }^{16}$ Discrimination on wages and benefits, working conditions and social protections are a kind of infringement on the rights of workers. Before preventing the violation of their rights, firstly, the employers have to respect and recognize their basic or fundamental rights as human beings, irrespective of whether they are internal workers or foreign workers. The very vital role of the protection of their rights involves the creation of fair and non-discriminatory rules and policies in the labour market.

Among the labour market regulations, minimum wages and working conditions will now be examined.

\subsection{Minimum Wages}

Each country or region has its own form of wages. Some countries regulate the minimum wage rate in their laws; on the other hand, some have a bargaining process involving employers and trade unions. ${ }^{17}$ When they set the rate for the workers, it is sure that the rate will depend on their skills and status. Most people may comment that the wages for highly skilled and skilled workers will be higher than

\footnotetext{
12 Annette Mummert, 'Employment and Labour Market Policies in Times of Economic Crisis' (2014) 19. <https:// www.academia.edu/7021761/Employment_and_Labour_Market_Policies_in_Times_of_Economic_Crisis> accessed 20 December 2020.

13 <https://www.ilo.org/empelm/areas/labour-market-policies-and-institutions/lang--en/index.htm> accessed 20 December 2020.

${ }^{14}$ Sandrine Cazes-Chaigne, 'Employment For Social Justice and a Fair Globalization, Overview of ILO programmes: Labour market analysis' <https://www.ilo.org/wcmsp5/groups/public/---ed_emp/documents/publication/wcms_140946.pdf> accessed 20 December 2020.

${ }^{15}$ Employment Policy Convention (1964) Art. 7. <https://www.ilo.org/dyn/normlex/en/f?P=NORMLEXPUB:1210 0:0::NO::P12100_ILO_CODE:C122> accessed 20 December 2020.

${ }^{16}$ Gordon Betcherman, 'Labor Market Regulations: What do we know about their Impacts in Developing Countries?' (2015) The World Bank Research Observer 125. <https://openknowledge.worldbank.org/handle/10986/24811> accessed 20 December 2020.

17 Ibid 129.
} 
for less-skilled level workers. It is the natural system in legislation dealing with employers and employment. Nevertheless, the ILO promulgates that the representative organizations of the employers and the workers, or if there is no organization, the representatives of the employers and the workers, shall negotiate and undertake to set the minimum wage.$^{18}$ Moreover, the ILO says that when they set the wage rate, they shall take into consideration two elements, the needs of workers and their families and economic factors. ${ }^{19}$ Guillaume Rocheteau and Murat Tasci also show that there are two kinds of markets: competitive and non-competitive labour markets. In the competitive labour market, many firms have their competitive demand and attract workers, but they cannot set the wage. In non-competitive labour markets, the major employer can do the wage rate without any competition..$^{20}$ Nathalie Elgrably said, "minimum wage is the entryway to the labour market for the least qualified individuals." $21 \mathrm{EU}$ member states are making progress regarding minimum wages for the workers in the region. (See Section 4 below.) In conformity with the facts mentioned above, the minimum wage is also crucial for the entry into the labour market of workers. Under ILO standards, the negotiation to set a minimum wage rate shall be made without any discrimination together with the representatives of the employers and the workers.

\subsection{Working Conditions}

The working conditions are mainly maternity protection, rules for occupational protection and safety and working hours. ${ }^{22}$ By seeing the working regulations, the job seekers can decide on their job situation. The ILO also mentions: "Working conditions cover a broad range of topics and issues, from working time (hours of work, rest periods, and work schedules) to remuneration, as well as the physical conditions and mental demands that exist in the workplace. ${ }^{23}$ Female workers need to get this kind of protection for their maternity leave. Moreover, maternity leave should be provided in a just and fair way. Together with their leave, they should also get their remuneration and this should not affect their employment. As the working time is stated in the employment contract, the rest periods should be mentioned. The work schedule shall not be unequal and unfair as they all have the fair working conditions under international human rights. Some working hours are much heavier for the

\footnotetext{
${ }^{18}$ Minimum Wage Fixing Convention (1970) Art. 4. <https://www.ilo.org/dyn/normlex/en/f?P=NORMLEXPUB: 12100:0::NO::P12100_ILO_CODE:C13> accessed 20 December 2020.

${ }^{19}$ Minimum Wage Fixing Convention, Art. 3.

${ }^{20}$ Guillaume Rocheteau and Murat Tasci, 'The Minimum Wage and the Labor Market' (2007) <https://www. clevelandfed.org/newsroom-and-events/publications/economic-commentary/economic-commentaryarchives/2007-economic-commentaries/ec-20070501-the-minimum-wage-and-the-labor-market.aspx> accessed 20 December 2020.

${ }^{21}$ Nathalie Elgrably, The Minimum Wage and Labour Market Flexibility (2006) Montreal Economic Institute, 2. <https://www.iedm.org/files/dec06_en.pdf> accessed 20 December 2020.

22 Mummert (n 12) 19.

${ }^{23}<$ https://www.ilo.org/global/topics/dw4sd/themes/working-conditions/lang--en/index.htm> accessed 20 December 2020.
} 
workers, so they do not have enough time to rest. Therefore, working conditions are also essential for labour market regulations.

\subsection{Active Labour Market Policies}

There are three kinds of labour market policies, which are regulatory labour market policy, active labour market policy and passive labour market policy. Regulatory labour market policy aims at guiding the negotiation and conclusion of employment contracts in a certain direction. Passive labour market policy aims at securing the subsistence costs during unemployment.

Active labour market policy (hereinafter: ALMP) is to adjust the workforce and jobs in an economy. ${ }^{24}$ ALMP emerged primarily in OCED and EU, and later in the Middle East and North Africa. Then Central and Eastern Europe and the CIS region also became interested in and implement ALMPs. ${ }^{25}$ ALMPs is related to the training, job creation in public programmes, self-employment promotion, etc. ${ }^{26}$ Active labour market policies were created in the early decades of the twentieth century. The role of ALMPs is to provide employment opportunities for unemployed workers and its aim is to know how to manage or set the tax regulations and programs made by the governments and to monitor the employment and wages' impact. ${ }^{27}$ Increasing the level of unemployment leads to positive effects on labour markets and introduced active labour market policies. ${ }^{28}$ It is essentially supporting unemployed people to find jobs. There are many rules and regulations on active labour market policies that provide the training system, the main creation of the supply and demand of workforce, and to raise some enterprises. It supports the labour market and job seekers as an important issue. Furthermore, ALMPs is important in training workers to attain high skills and promote employment productions. ALMPs are being used across Europe beneficially and crucially. Therefore, in the next section, the role of ALMPs in Europe will be mentioned as well.

\section{Labour Market Regulations in the EU}

European organizations are leading to a single market within their region and still trying to to get better regulations. In the enlargement of Europe, the integra-

\footnotetext{
${ }^{24}$ Mummert (n 12) 20.

${ }^{25}$ Andrei Jean, Cvijanovic Drago and Zubović Jovan, 'The role of labour markets and human capital in the unstable environment' (2011) < https://www.researchgate.net/publication/228279666_The_Role_of_Labour_ Markets_and_Human_Capital_in_the_Unstable_Environment> accessed 20 December 2020.

${ }^{26}$ <https://www.eqavet.eu/eu-quality-assurance/glossary/active-labour-market-policies-(almps)> accessed 20 December 2020

27 Anna Bánociová and Slavomíra Martinková, 'Active Labour Market Policies of Selected European Countries and Their Competitiveness' (2017) 9(3) Journal of Competitiveness 6. <https://www.cjournal.cz/files/254.pdf> accessed 20 December 2020.

${ }^{28}$ Andrei Jean, Cvijanovic Drago and Zubović Jovan (n 25) 4-21.
} 
tion is also broader and stronger in the economic cooperation and social policies, especially in connection to labour mobility. European member countries have the right of free flow of labour migration within the region. The European Union has to coordinate its economic, social rights, and their political integration. Therefore, they take care of the social rights of the workers in their labour market. The EU is more interested in single labour market than common labour market. Its intention is to be just and fair regarding all the rules and regulations and not to cause conflict between Member States about the equilibrium. By setting up the single market, the EU is a united organization and a real single space with the same rules and policies. It makes the EU more equitable and a uniform platform for many citizens. There were so many policies and regulations of the labour market in the EU from the past up until today. However, these attempt to create a stable and high standard policy that will allow Member States to make higher profits and increase opportunities, and from the angle of the economic integration, their business increases and become more profitable because it gives the the effective machinery of their productivity.

European countries are always discussing labour market policies for the protection of jobseekers and for increasing employment. With the Maastricht Treaty, the European Union allows the people of the member countries to have the right to work throughout the Union. The European Employment Strategy (EES) integrated with the international labour market and employment policies of the Member States intends to make the labour markets equal. European citizenship and unification of the law compels the Member States to act as a single state. The EU is focusing on social policy as one of the important areas to improve upon. Therefore, the social policy was built for the working conditions within the EU, to bring about a dialogue between employers and workers and to ensure compliance between the Member States. ${ }^{29}$ The provision of LMPs is highly heterogeneous across the EU. ${ }^{30}$ When the market policies would be restricted for workers, the labour demand would not be supported and it is hard to fulfil the workers' needs. Furthermore, productivity would also be slower and slower. However, if it is restricted for the employers, the workers' job opportunities will get higher and from the perspective of the employers, they would cost the expenditures of the labour demand, but their productivity and the circuit of their business would be faster and effective.

European minimum wages play a vital role in the labour market by virtue of the worker's decent living within the region. There are two systems of setting a minimum wage in the EU which are through the statutory minimum wage and though the collective bargaining. Twenty-one member states of the EU are processing their rate with their statutory minimum wage, but six members (Austria, Cyprus, Denmark,

${ }^{29}$ Sefer Sener and Burcu Kılınç Savrul, 'Europeanization of Labour Markets in New Member and Candidate States' (2011) 24 Procedia - Social and Behavioral Sciences 716 (DOI 10.1016/j.sbspro.2011.09.053).

${ }^{30}$ Lorenzo Ciapetti, 'Uncoordinated Job: EU Labour Market Policies' Reaction since the Crisis' (2017) Antares and Centre for Comparative Public Policy Policy Brief N. 1/2017 4. <https://www.academia.edu/32793471/ UNCOORDINATED_JOB_EU_LABOUR_MARKET_POLICIES_REACTION_SINCE_THE_CRISIS > accessed 20 December 2020. 
Finland, Italy and Sweden) go through collective bargaining. ${ }^{31}$ In October 2020, the EU promulgated the Proposed Minimum Wage Directive to ensure the workers in the Union have a decent living wherever they work. The Directive is correlated to the two minimum wage systems mentioned above. ${ }^{32}$

The European Council adopted the Lisbon Strategy in 2000 for raising the employment rate. Its aim is "the most competitive and dynamic knowledge-based economy in the world, capable of sustainable economic growth with more and better jobs and greater social cohesion." 33 The European Council provided a recommendation of the integration of the long-term unemployed in 2016. It encourages the increasing of the employment rate and the reduction of poverty. ${ }^{34}$ The Directorate General for Economic and Financial Affairs always assesses the European labour market depending on the labour market indicators and on other aspects, especially the labour market issues and labour market reforms. Moreover, the European Commission also figures out the tax and benefits systems about the contributing of economic growth and higher employment for the social protection. ${ }^{35}$ European internal market law gives the guarantee directly for the business, free movement rights, self-employed persons and companies. ${ }^{36}$ Tito Boeri, Giuseppe Nicoletti and Stefano Scarpetta argue that

"the effective coverage or implementation of standard employment protection provisions influences the overall strictness of EPL regulations. For example, in many countries employment protection provisions for workers with regular contracts are often extended to those with fixed-term contracts after a given tenure or number of renewals has been reached." ${ }^{37}$

The European labour market policy includes labour taxation, unemployment benefits, other welfare-related benefits, active labour market policies, job protection (EPL), wage setting, working time and immigration mobility. ${ }^{38}$ Among these policies, active labour market policies and immigration mobility (labour migration and EU labour market) will be stipulated separately.

31 <https://www.europarl.europa.eu/thinktank/hu/document.html?reference=EPRS_BRI\%282020\%29659294> accessed 20 December 2020.

32 Proposal for a Directive of the European Parliament and of the Council on Adequate Minimum Wages in the European Union <https://eur-lex.europa.eu/legal-content/EN/TXT/PDF/?Uri=CELEX:52020PC0682\&from= EN> accessed 20 December 2020.

33 <https://portal.cor.europa.eu/europe2020/Profiles/Pages/thelisbonstrategyinshort.aspx> accessed 20 December 2020.

${ }^{34}$ European Commission European Semester Thematic Factsheet: Active Labour Market Policies (2017) <https:// ec.europa.eu/info/sites/default/files/european-semester_thematic-factsheet_active-labour-market-policies_ en_0.pdf> accessed 20 December 2020.

35 <https://ec.europa.eu/info/business-economy-euro/growth-and-investment/structural-reforms/labour-markets_en> accessed 20 December 2020.

${ }^{36}$ Dagmar Schiek, 'Comparing Labour Laws in the EU Internal Market - A Social Actor Perspective' (2017) 33(1) International Journal for Comparative Labour Law and Industrial Relations 171.

37 Tito Boeri, Giuseppe Nicoletti and Stefano Scarpetta, 'Regulation and Labour Market Performance' (1999) IGIER Working Paper No. 158 <https://ssrn.com/abstract=201748> accessed 20 December 2020 (DOI 10.2139/ssrn.201748).

$38<$ https://webgate.ec.europa.eu/labref/public/> accessed 20 December 2020. 
In this section it is argued that flexible labour market in Europe needs to be stated as the EU is trying to get the flexibility in its labour market. Active labour market policies in Europe will be extended by referring to some authors and European Commission policies. Furthermore, the expenditures on ALMPs have to be expressed more as training and other job seeking assistances are included. Finally, labour migration and labour market in Europe will be stated because this is essential and of important. I will discuss how the situation of labour migration and labour market in Europe is and how much protection and security the migrant workers will get from the labour market. After referring to the scientific literature related to my sub-topics, my theoretical factors will be added.

\subsection{Flexible Labour Market in Europe}

During the last decades, the European Union was eager to be flexible in the labour market by revising their policies and regulations between Member States leading to a single labour market in EU because the EU gradually is moving towards that kind of market from 27 separate national labour markets. ${ }^{39}$ The aim of the single market is to bring about just, fair and equal services, skill, promotion and performances within the region and to ensure the free movement of goods, services and workers. By creating the single market, the unfairness and wage problems will be reduced and workers and employers can cooperate freely without any dispute.

It cannot be argued that the single market create a flexible labour market. Somehow, even if the flexible labour market is implemented, the social dimension needs to be described as the substantial rules. There is a European Pillar of Social Rights that protects social rights of the workers. Nóra Jakab said that the principle of equal treatment is the vital social dimension of the EU and the pillars' principles are for the social and labour market agenda. ${ }^{40}$

\subsection{Active Labour Market Policies in the EU}

When facing the economic crisis in 2008, the EU established the European 2020 Strategy that also includes a section of active labour market policies among the services. It is the main method for solving the challenge of unemployment. ${ }^{41}$ Because it is one part of the European 2020 Strategy, it can be said to be essential for employment development and to reduce unemployment within Europe.

39 Iván Martín and Alessandra Venturini, 'A Comprehensive Labour Market Approach to EU Labour Migration Policy' (2015) 3. <https://op.europa.eu/en/publication-detail/-/publication/824e91bc-d642-4626-9267676945e15053/language-en> accessed 20 December 2020 (DOI 10.2870/753878).

${ }^{40}$ Nóra Jakab, 'Social Dimension of the EU - The Pillar's Impact on European Labor Law' (2019) 26(2) LESIJ - Lex ET Scientia International Journal 53.

41 Jochen Kluve, 'The Effectiveness of European Active Labour Market Policy' (2006) IZA Discussion Paper No. 2018 2. <http://ftp.iza.org/dp2018.pdf> accessed 20 December 2020. 
According to the LABREF Database, active labour market policies are: public employment services (e.g. job counselling and job assistance, etc.), training, direct job creation schemes, and employment subsidies, special schemes for the disabled, special schemes for youth, active labour market policies, among others. ${ }^{42}$ Many authors argue that there are six types of ALMPs, which are training, private sector incentive program, direct employment program in the public sector, service and sanction, youth programs and measures for the disabled. Training means specific vocational skills or education in order to enhance productivity and human capital. Private sector incentive programs are a kind of encouragement to the employers to provide new jobs for the unemployed and migrant workers. Direct employment programs in the public sector implies the direct creation and provision related to the public works for the public goods and services and aims at disadvantaged individuals Some services and sanction for the unemployed are mainly relevant to the assistance of the job searching for the unemployed individuals. Youth programs are a kind of particular program that is for the disabled youth and unemployed. Measures for the disabled give the opportunity for the physically, mentally or socially disabled. It includes vocational rehabilitation, sheltered work program and wage subsidies. ${ }^{43}$

The restructuring of the labour market, the social welfare reforms and European employment strategy's agreements improvement are the causes of the emergence of ALMPs in EU. ${ }^{44}$ In 1990, it was an important policy in the EU in terms of entering the labour market for the unemployed and inactive persons. The European Pillar of Social Rights includes a reference to ALMPs. ${ }^{45}$ According to the facts mentioned above, the active labour market policies are the vital regulations and rules of the European labour policy. From my point of view, the ALMPs in Europe are nearly perfect in attempting to get more jobs for the unemployed. Besides, it can support and promote productivity and the skills of the workers. However, the Member States do not seem to have the same practice regarding ALMPs. They may differ depending on their country's economic situation. Nevertheless, Europe is moving towards a single labour market to be fair and equitable between the workers of the Member States. Some differences in the use of ALMPs in certain EU countries will be stated in the following pages. Youth job seekers have great opportunities to find jobs as ALMPs especially favour the unemployed youth. Therefore, it is a kind of supporting platform for the workers and employers.

Young European workers who are unemployed are targeted by the active labour market policies. ${ }^{46}$ The original intention of ALMPs for youth is that the unemployed youth enter the labour market to start their career by undertaking vocational training.

42 <https://webgate.ec.europa.eu/labref/public/> accessed 20 December 2020.

43 Jochen Kluve et al., Active Labor Market Policies in Europe (Springer 2007).

44 Willibrord De Graaf and Andréana Khristova, 'Active labour market policies and social rights: wither subsidised employment?' (2005) International Conference: Employees' Resources and Social Rights 3. <https:// www.boeckler.de/pdf/wsi_resore_de_graaf.pdf> accessed 20 December 2020.

${ }^{45}$ European Commission European Semester Thematic Factsheet: Active Labour Market Policies (2017) <https://ec.europa.eu/info/sites/default/files/european-semester_thematic-factsheet_active-labour-market-policies_en_0.pdf> accessed 20 December 2020.

46 Jochen Kluve et al. (n 43) 3. 
There is an educational mismatch among the youth in the labour market. The unemployment rates are rising in Europe.$^{47}$ Hence, the ALMPs can provide the low-skilled or unskilled youth with the effective training to prepare for employment. In comparing the skills of the youth with adults and old people, it is clear that their skills are much less than these two latter groups. Moreover, they do not have any experience in employment. The adults and the old do not need to be trained as most of them already have necessary skills and experiences. Regarding the youth, they move into employment when they finish school. This is the reason why ALMPs focuses on the unemployed youth. The more skilled young people the labour market has, the more stable their employment and productivity can be more effectively developed.

\subsection{The Expenditure on ALMPs in Europe}

The expenditure on ALMPs is not the same in all countries, it differs according to their financial systems and other practices among Member States. Before the economic crisis in 2008, France, Italy, Portugal, Spain, Greece and Austria (continental and Mediterranean countries) used less than $1 \%$ of GDP and the Scandinavian countries above 1\% of GDP on ALMPs. In 2012 and 2013, several European member states reduced their budget for ALMPs expenditure, nevertheless, Denmark, Finland, Norway and the United Kingdom increased their expenditure to a level higher than the expenditures in the economic crisis. ${ }^{48}$

The public expenditure on ALMPs in 2007 before the job crisis was low in many European countries. Less than $0.2 \%$ of GDP was spent in Estonia, the Czech Republic, Latvia, Slovakia, and Slovenia. Over the next years, the expenditure on ALMPs in the EU countries changed across countries and over time. The average ALMPs expenditure in selected European countries was $0.35 \%$ of GDP (2007) and $0.43 \%$ of GDP in the following years. ${ }^{49}$ According to the economic, political and financial systems, the expenses differ in each Member State. In fact, the benefits are not based on the expenditure on ALMPs among Member States. The vital aim of the ALMPs is not to increase the unemployment rate in the future and to support long-term unemployment. To get an effective training in the employment it needs skilled and talented trainees to train the workers. Nevertheless, the expenditures also play an important role in the labour market.

\subsection{Labour Migration and the European Labour Market}

The European Union always attempts to bring about good cooperation between Member States by being flexible in some affairs. When the Union was organized, the

\footnotetext{
${ }^{47}$ Marco Caliendo and Ricarda Schmid, 'Youth Unemployment and Active Labour Market Policies in Europe' (2016) 5(1) IZA Journal of Labor Policy 6. (DOI 10.1186/s40173-016-0057-x)

${ }^{48}$ Marwa Sahnoun and Chokri Abdennadher, 'The assessment of active labor market policies: evidence from OECD countries' (2018) 35(2) Economia Politica (DOI 10.1007/s40888-018-0102-x).

49 Anna Bánociová and Slavomíra Martinková (n 27) 11.
} 
labour migration flow was the main focus for the businesses because they also allow for the free movement of workers. European workers have been migrating from their country to other member states since the organization was founded. As the EU grew with new members, the migration flow has also increased. It is related to the internal migration flow in the EU. There is another kind of migration flow from the third country nationals who are not the members of EU. Gábor Mélypataki also mentions that two different migration processes in Europe: from the south to the north and from the east to the west..$^{50}$ In any case, whether all migrant workers are allowed to take part in the labour market and the kind of opportunities available to them shall be taken into consideration. It is sure that European citizens can get the same opportunities as the nationals of the receiving states. However, what is the situation with regards to external migrant workers (third country nationals)?

Economic growth raises labour supply and labour demand, therefore, it increases labour mobility and demand for balancing and filling the gaps and support. For the shortages of workers, the migrant workers are needed as labour force. Internal migration of workers represents a very important phenomenon to ensure the labour market flexibility. ${ }^{51}$ Van Der Gaag and Wissen stipulate that there are four categories in labour migration determination: gravity variables, economic variables, labour market variables and environmental variables. The four categories are helpful and supportive in scrutinizing the labour market and labour migration. Owing to the large organization of the EU, labour shortages often appear even though the free movement of workers is recognized. There are some reasons; including this fact, that allows the migrant workers from outside the EU. Immigrants also have the opportunity to get jobs in many vacant positions but the same protection to all migrants needs to be given. Many European Member States are requesting many workers within and out of the EU. The policies and protection of their employment security and rights are different in each Member States' system. However, the fundamental or basic rights shall be provided according to their internal legislation.

EU labour market's evaluations and projections show the necessary migrant labour force in the future. The EU labour market policy should intend to complete the EES in the ways of accepting the international migrant workers to fill vacancies in intra-EU labour and skills supply. ${ }^{52}$ This simple model is that migrants and natives are homogeneous units of labour. Nevertheless, in practice it depends on different skills and abilities. If there are more different skills in the labour market, the competition with the natives will be less. At the same time, immigrants' wages will be reduced due to their low skills. ${ }^{53}$ In accordance with the facts mentioned above, the migrant workers from outside the EU cannot get the competition and the equal remuneration

\footnotetext{
${ }^{50}$ Gábor Mélypataki, 'Effects of Migration on Employment Policy and the Coordination of Social Security Systems' in Tímea Barzó et al. (eds), Modern Researches (Miskolci Egyetem 2020) 93, 94-95.

51 Ailenei Dorel and Bunea Daniela, 'Labour Market Flexibility In Terms Of Internal Migration' (2010) 1(1) Annals of Faculty of Economics, University of Oradea, Faculty of Economics 153, 160 and 163.

52 Iván Martín and Alessandra Venturini (n 39) 5.

${ }^{53}$ Madeleine Sumption and Will Somerville, 'Immigration and Labour Market: Theory, evidence and policy' (2009) Migration Policy institute 9. <https://www.migrationpolicy.org/sites/default/files/publications/lmmigration-and-the-Labour-Market.pdf> accessed 20 December 2020.
} 
thanks to the reason that the EU can give a favour to the European citizens in the intra-EU migration. However, I argue the fact that migrants from third countries get the opportunity to compete in the labour market even if they have the skills that the employers actually need and regulate. In the case that such skilful migrant workers do not have any equal wages or security like nationals, we cannot say that it is fair.

\subsection{Pandemic Situation and European Labour Market}

Since 2020, the Covid pandemic is being faced around the world and impacts upon every system (education, economic, social, health, etc.). While some employment can be kept by working from home, some employment such as manufacturing and production is necessarily closed down and cease during the time of the pandemic's duration. Unfortunately, by now this state of affairs has not been for a short period, but continues up until the present day. Most European countries are undergoing the rise of infected patients. The ILO also estimated that compared to other regions, Europe presents one of the largest losses in hours worked. ${ }^{54}$ When we consider the impact of the Covid pandemic on the labour market in the EU, it is clear that not only workers but also the employers are at risk of losing their decent living standards and business ties.

The euro area labour market has been severely hit by the coronavirus pandemic and associated containment measures. EU governments tried to devise polices to save the labour market. ${ }^{55}$ The EU's new measures for solving the risks are divided into five sectors (essential and fully active sectors): (1) active but via telework, (2) mostly essential and partly active, (3) not telework able, (4) mostly non-essential and inactive and (5) not telework able and closed. The measures are virtually concentrating on women and young workers more than any other groups. ${ }^{56}$ The most admirable thing is that the businesses are not stopped and kept on operating under the confinement measures. The machinery is still turning to be normal. In this situation, the rules of the EU labour market are in a condition of being handled carefully without any mistakes.

\section{Conclusions}

The aim of the labour market is to fill the gaps in employments and to balance the labour supply and labour demand. The European Union emphasizes the labour

$54<$ https://www.eurofound.europa.eu/events/how-covid19-affects-europeans-and-eu-labour-market> accessed 20 December 2020.

55 Robert Anderton et al., 'The Impact of Covid 19 Pandemic on the Euro Area Labor Market' (2020) 8 ECB Economic Bulletin <https://www.ecb.europa.eu/pub/economic-bulletin/articles/2021/html/ecb.ebart202008_ 02 bc749d90e7.en.html> accessed 20 December 2020.

${ }^{56}$ Sergio Torrejón et al., 'The Impact of Covid Confinement Measures on EU Labor Market' (2020) European Commission Science for Policy Briefs <https://ec.europa.eu/jrc/sites/jrcsh/files/jrc.120585_policy.brief_impact.of_.covid-19.on_.eu-labour.market.pdf> accessed 20 December 2020. 
market in order to integrate economic growth and to create a single labour market among Member States. The intention of the single labour market in the EU is to bring about common policies, common services, common goods, and the free movement of workers.

The EU is implementing active labour market policies to reduce the unemployment rates and to increase the number skilful workers in order to promote productivity and employment. The active labour market policies are especially for the youth who are not skilful and do not have any work experience. According to these policies, the youth will receive training, the opportunities to get jobs and finally, it is essential to the EU Member States. Therefore, they have better chances than adults and the elderly who have greater experience in employment. ALMP is based on employers setting the rules and regulations within the workplace or employment. With unemployed workers providing training to unemployed workers, they will contribute to the expenditures in supporting the guidance of the improvement of the workers.

Finally, I wish to talk about labour migration and the labour market within the EU. With the enlargement of European Union, the migration flows have also increased in the last few decades. Labour migration is allowed in terms of the free movement of workers. Therefore, for intra-EU immigrants it is easy to get jobs through the labour market. It also can guarantee the opportunities to possess equal rights like nationals in the receiving countries. The European Union has the agreement of the Member States in the area of social rights. However, the important point and fact is that workers who are not European citizens cannot get the same rights as nationals in the receiving countries. Nevertheless, the labour market can also give opportunities to find jobs for third country workers. Although the workers can find job opportunities through the European labour market, they tend to get jobs in agriculture, dangerous places, etc. The EU needs many engineers for their technology promotion that third country nationals can apply to be engineers within the EU. However, we cannot say it is not fair and just under the international labour standards and human rights standards. Since the EU was organized among member countries with their agreements, it means that they will cooperate and collaborate in the social, political, economic, educational areas. Every region has its own policies and protocols the member countries in a favourable position and is trying to raise their economic and social affairs. For non-Member States, they cannot give them the same favourable conditions and rights as for their own nationals or member state citizens. This is because they do not have any cooperation for a long term and there is not support in the affairs among them.

Moreover, labour market regulations need to be flexible not to face illegal migration. If the market rules or policies too strict, many challenges about the irregular cases would be faced. By restricting the labour market with certain strict rules, workers would find another way to get jobs and opportunities. It may be done by illegal means or the ways the receiving country is deterring as a block manner. The employers and businessmen are likely to get cheap labour or immigrants entering the states in an illegal manner. The only reason is that they can reduce their expenditures on the labour costs and can make their industry or improve their productivity within a short time. They do not need to spend such long periods of time in their factories. 
From my point of view, a flexible labour market should be created for preventing the issues of illegal workers and unequal social rights within the workplace. Actually, it relies on the employers who can set the rules and regulations within their company or employments. The rights of the workers are depending on the labour market regulations or policies.

Therefore, I have to give my answers to the questions asked in the hypothesis: (1) The role of the labour market for migration is good in the EU as it allows every worker to participate in the labour market according to the market regulations. Nevertheless, for the non-European workers, they will not have the same or equal rights and security as the European national workers. (2) Yes, the EU should have a flexible labour market, but if there were such flexible regulations, the opportunities would be less. The labour market should be flexible with some limitations for the prevention of shortages in employment. (3) Yes, the pandemic situation totally affected the EU labour market. 